\title{
EXTENDING THE GEOGRAPHIC DISTRIBUTION OF BRYODRILUS EHLERSI (ANNELIDA, ENCHYTRAEIDAE): MORPHOLOGICAL AND MOLECULAR COMPARISON OF KOREAN AND EUROPEAN SPECIMENS
}

\author{
Hajnalka Nagy ${ }^{1}$, KLÁra Dózsa-Farkas ${ }^{2}$, Yong Hong ${ }^{3, *}$ and Tamás Felföldi ${ }^{4, *}$ \\ ${ }^{1}$ Department of Microbiology, Eötvös Loránd University \\ H-1117 Budapest, Pázmány Péter sétány 1/C, Hungary \\ E-mail: nhajni6@gmail.com, https://orcid.org/0000-0001-6798-8701 \\ ${ }^{2}$ Department of Systematic Zoology and Ecology, Eötvös Loránd University \\ H-1117 Budapest, Pázmány Péter sétány 1/C, Hungary \\ E-mail: kdozsafarkas@gmail.com, https://orcid.org/0000-0003-3372-2838 \\ ${ }^{3}$ Department of Agricultural Biology, College of Agriculture and Life Science \\ Jeonbuk National University, Jeonju 54896, Korea \\ E-mail: geoworm@hanmail.net,https://orcid.org/0000-0002-1932-4983 \\ ${ }^{4}$ Department of Microbiology, Eötvös Loránd University \\ H-1117 Budapest, Pázmány Péter sétány 1/C, Hungary \\ E-mail: tamas.felfoldi@gmail.com, https://orcid.org/0000-0003-2009-2478 \\ *corresponding authors
}

During the study of the enchytraeid fauna of South Korea, specimens were found, which were identified as Bryodrilus ehlersi based on their morphological characters. This was an unexpected result since this species is common in Northern and Central Europe but has not yet been found in the Far East. Furthermore, sequence analysis of the mitochondrial cytochrome c oxidase subunit I gene, the nuclear histone 3 gene and the nuclear ribosomal ITS region showed unambiguously that the specimens collected in South Korea represent a different evolutionary lineage. In this paper, the detailed morphological and molecular comparison of Bryodrilus ehlersi specimens collected from various sites and countries are presented. Although the Korean specimens could not be formally described as a different species due to the lack of studied specimens from the type locality, clear evidence of cryptic genetic diversity was found within Bryodrilus ehlersi.

Key words: Enchytraeidae, cryptic diversity, Bryodrilus ehlersi, South Korea, molecular taxonomy.

\section{INTRODUCTION}

Molecular techniques that supplement morphological methods have become extremely important in taxonomic studies. There are so-called "cryptic species", that differ genetically but their morphology is very similar, therefore cannot or can only be hardly differentiated with traditional morphological methods, and they can be identified and distinguished only by means of molecular analyses (Schmelz et al. 2017, and references cited therein). In the Enchytraeidae, several new cryptic species have already been described, e.g., 
Enchytraeus crypticus Westheide et Graefe, 1992, Cognettia pseudosphagnetorum Martinsson et al., 2015 and C. varisetosus Martinsson et al., 2015 and C. asloae Martinsson et al. 2018. According to Schmelz et al. (2017) and MARTinsson et al. (2018), if two species are morphologically hardly distinguishable or indistinguishable, they can be considered as cryptic species pairs [e.g., C. sphagnetorum (Vejdovský, 1878) and C. pseudosphagnetorum]. Sometimes, DNA-based studies have aided the recognition of distinct evolutionary lineages within the same morphospecies, but the formal description of a new species is yet to be done, e.g., in the case of specimens morphologically identified as Achaeta danica (Dózsa-Farkas \& Felföldi 2017), Cernosvitoviella minor (Dózsa-Farkas et al. 2017) and Fridericia seoraksani (Dózsa-FARKAs et al. 2015). Furthermore, clear evidence of cryptic diversity was also found within the genus Marionina (Matamoros et al. 2012) and, more recently, in Globulidrilus, Hemifridericia and Stercutus (Martinsson \& Erséus 2018).

Molecular methods provide an opportunity to verify the identity of morphologically slightly different enchytraeids previously described as separate species and whether these dissimilarities should be considered as intraspecific variations and synonymization should be performed. In the case of the Bryodrilus genus, which is the subject of this study, this has already been done when Bryodrilus parous Nurminen, 1970 was synonymised with B. librus (Nielsen \& Christensen, 1959) (Dózsa-Farkas et al. 2012), and Bryodrilus glandulosus Dózsa-Farkas, 1990 was synonymised with Bryodrilus ehlersi Ude, 1892 (СЕCH et al. 2012).

A suspected case of cryptic species was observed in Bryodrilus ehlersi Ude, 1892 s.l. when comparing specimens from South Korea with those collected from the previously known distribution area of this species (northern and central regions of Europe). Our ongoing research project on the enchytraeid fauna of South Korea is based on soil samples collected in 2016 and 2017, and specimens have been identified, as suggested by Schmelz et al. (2017), using a combination of morphological and molecular analyses. Taxonomic and faunistic results have been partly published with the description of twelve species and one genus new to science (Dózsa-FArKas et al. 2018, 2019a,b), while in this paper, based on specimens from this sampling campaign, the comparison of Korean and European Bryodrilus ehlersi specimens is given.

\section{MATERIAL AND METHODS}

Abbreviations: cf. $=$ confer, $\mathrm{CO} 1=$ Cytochrome c Oxidase subunit I, H3 = Histone 3, ITS = Internal Transcribed Spacer, PCR = Polymerase Chain Reaction. Institutional abbreviations: NIBRIV = National Institute of Biological Resources, Korea

Morphological methods - Specimens were collected in South Korea (Mt. Deogyu and Mt. Odaesan), Germany and Hungary (see details in Table 1 and in the species description). Worms were extracted from soil by the wet funnel method (O'ConNor 1962). Enchytraeids 
were first observed and measured alive, then fixed and preserved in $70 \%$ ethanol for DNAbased analysis. Some of the specimens were stained with borax-carmine, and then passed through an ethanol dehydration series (from $70 \%$ to absolute), mounted temporarily in clove oil, then permanently in Euparal between two coverslips. Hence the worms were observable from both sides (Schmelz 2003). All the important morphological characters were recorded in vivo, drawn and photographed [Axio Imager.A2 microscope with differential interference contrast illumination, AxioCam MRc 5 (Zeiss) digital camera, Axiovision software]. The whole-mounted specimens were reinvestigated and photographed as well. In all micrographs presented in this study, the orientation of specimens is the same: the head is either on the left side or on the top of the picture. Reference material of selected studied specimens was deposited in the National Institute of Biological Resources, Korea ("NIBRIV").

DNA-based methods - Genomic DNA was extracted with the DNeasy Blood \& Tissue Kit (Qiagen) according to the instructions given by the manufacturer. CO1 and H3 genes and the ITS region were amplified separately by PCR using the primer pairs HCO2198 (5'-TAA ACT TCA GGG TGA CCA AAA AAT CA-3') and LCO1490 (5'-GGT CAA CAA ATC ATA AAG ATA TTG G-3') (Folmer et al. 1994), H3a-F (5'-ATG GCT CGT ACC AAG CAG ACV GC-3') and H3a-R (5'-ATA TCC TTR GGC ATR ATR GTG AC-3') (ColgAn et al. 1998), ETTS1 (5'-TGC TTA AGT TCA GCG GGT-3') and ETTS2 (5'-TAA CAA GGT TTC CGT AGG TGA A-3') (KANE \& Rollinson 1994), respectively. PCRs and sequencing were performed as described in detail previously by DózsA-FARKAs et al. (2015). Sanger sequencing was carried out by the LGC Genomics GmbH (Berlin, Germany) and by the Biomi Ltd. (Gödöllö, Hungary), while the maximum likelihood analyses including the search for the best-fit model were performed with the MEGA 7 software (KumAR et al. 2016). Additionally, a concatenated analysis with discrete substitution models was performed. For this, concatenation was carried out with Sequence Matrix version 1.8 (VAIDYA et al. 2011). Bayesian analysis was performed with the Markov Chain Monte Carlo algorithm in two simultaneous, completely independent analyses running for 1000000 generations using MrBayes version 3.1 (Huelsenbeck \& Ronquist 2001). Posterior probabilities were calculated after the two independent runs had reached convergence, and the first $25 \%$ of the calculated trees were discarded.

The obtained sequences were deposited in GenBank under the following accession codes: MK098303-MK098308 (H3), MK098309-MK098314 (CO1) and MK108074-MK108077 (ITS).

\section{RESULTS}

\section{Morphological characterization of the Korean Bryodrilus ehlersi specimens}

Korean material deposited - In total, 14 stained, adult specimens on slides. NIBRIV0000831786, slide No. 2675, adult, stained, whole mounted specimen, Mt. Deogyu, Seolcheon-meyon, Muju-gun, Jeollabuk-do, South Korea, decaying wood debris, soil and litter layers, $35^{\circ} 51^{\prime} 39.9^{\prime \prime} \mathrm{N}, 127^{\circ} 45^{\prime} 22.9^{\prime \prime} \mathrm{E}, 1245 \mathrm{~m}$ a.s.1., 21.09.2016, Leg. Yong Hong. NIBRIV0000831787, slide No. 2411 (DNA ID 1078), NIBRIV0000831788, slide No. 2632., P.124.1.1-124.1.9, slides No. 2465-2466, 2579-2580, 2633, 2671-2674, 11 specimens, same data as above. P.124.11-124.12, slides No. 2604, 2631 (DNA ID 1295), 2 specimens, Waljeongsa, Mt. Odaesan, Dongsan-ri, Jinbu-myeon, Pyeongchang-gun, Gangwon-do, South Korea, decaying wood debris, soil and litter layers in Abies holophylla forest, $37^{\circ} 43^{\prime} 36.9^{\prime \prime} \mathrm{N}$, $128^{\circ} 35^{\prime} 47.5^{\prime \prime} \mathrm{E}, 630 \mathrm{~m}$ a.s.l., 01.11.2017, Leg. Yong Hong. 


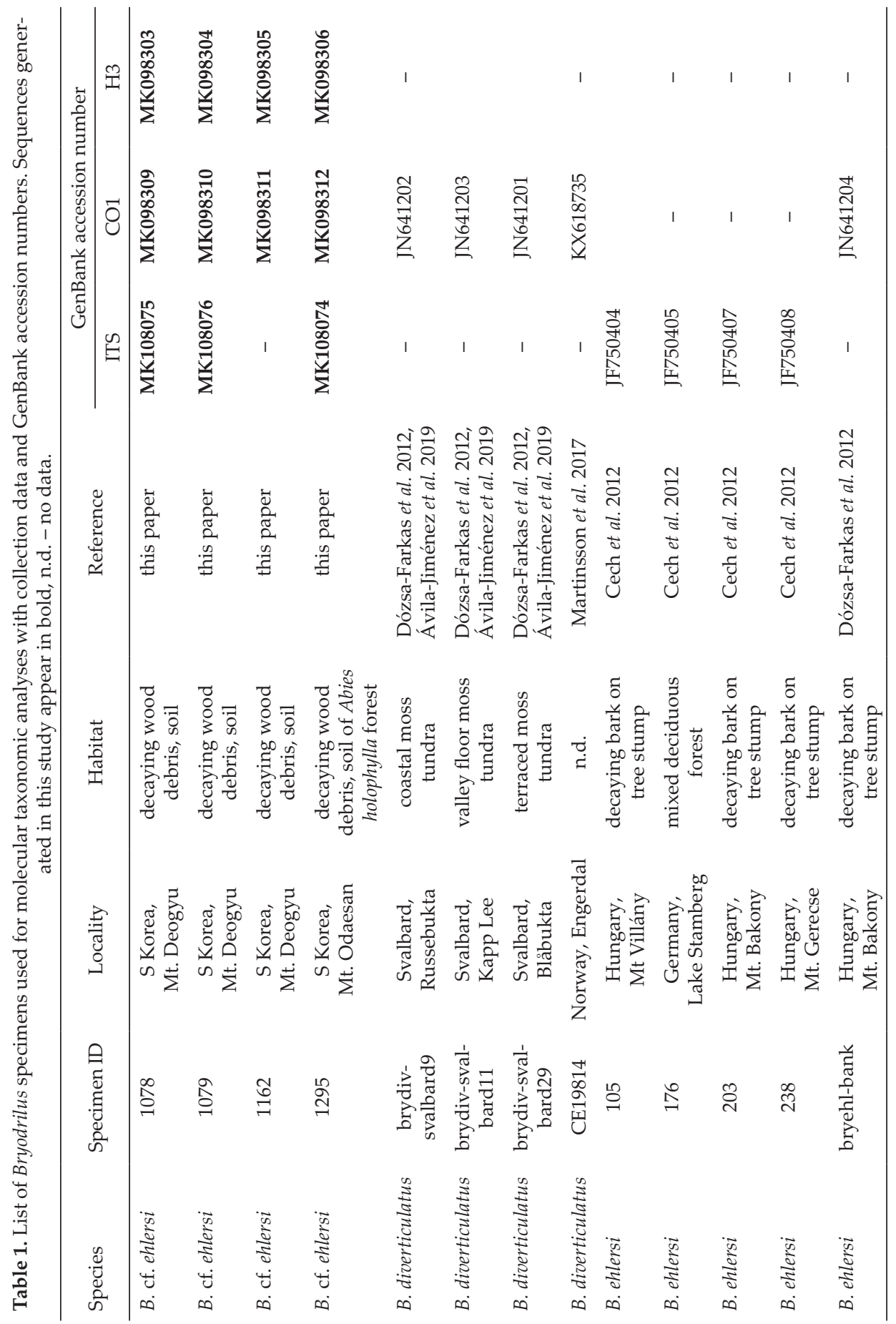




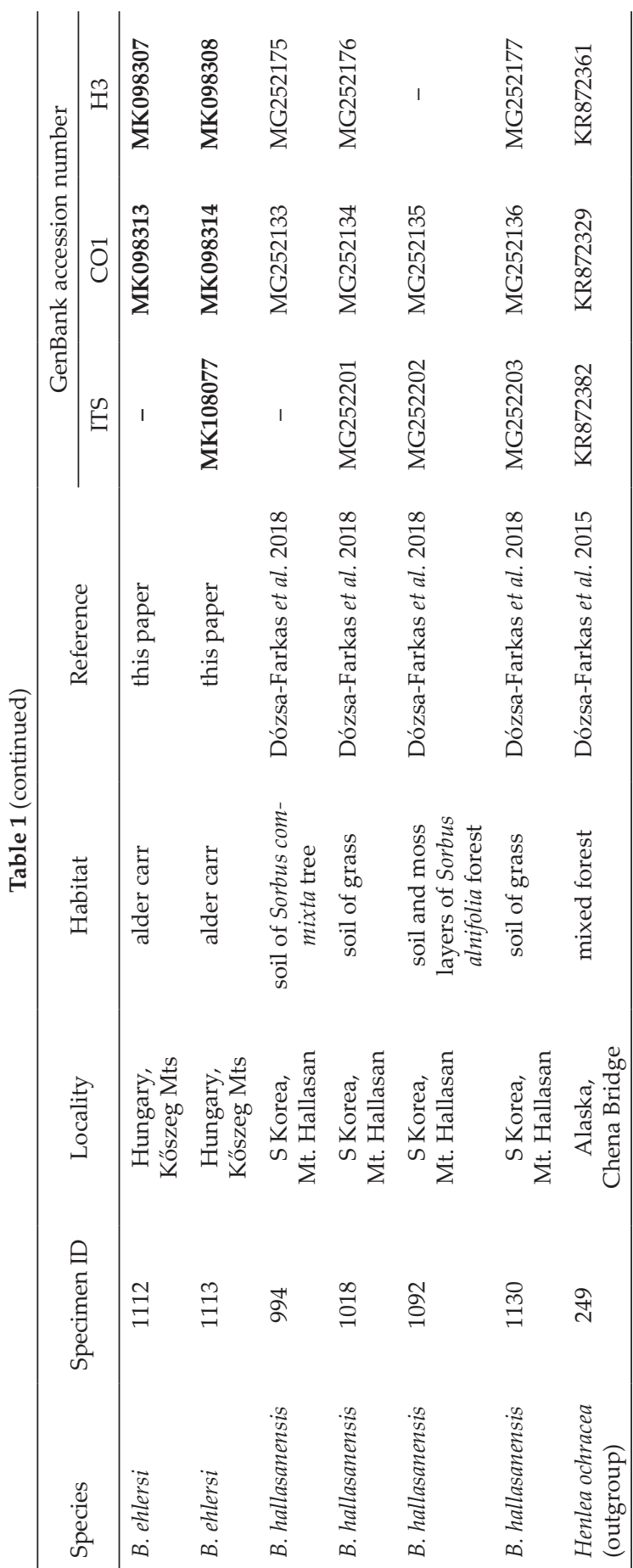

Additional material examined from Korea -4 subadult specimens and 2 specimens only alive from the type locality.

Comparative material from Europe - Hungary: 2 specimens, Kőszeg Mts, near Paprét, alder carr at a creekside, $47^{\circ} 24^{\prime} 05.5^{\prime \prime} \mathrm{N}$ $16^{\circ} 26^{\prime} 52.7^{\prime \prime} \mathrm{E}, 478 \mathrm{~m}$ a.s.1., 21.05 . 2014, Leg. Klára Dózsa-Farkas, János Farkas, Zoltán Tóth (DNA ID 1112 and 1113); 10 specimens, Börzsöny Mts, Királyrét, decaying bark on tree stumps, $47^{\circ} 56^{\prime} 14.6^{\prime \prime} \mathrm{N} \quad 18^{\circ} 56^{\prime} 26.2^{\prime \prime} \mathrm{E}, 774$ $\mathrm{m}$ a.s.l., 17.10.2017, Leg. János Farkas; 1 specimen, Mt. Villány, Szársomlyó, oak forest with Ruscus aculeatus, decaying bark on tree stump, $45^{\circ} 51^{\prime} 25^{\prime \prime} \mathrm{N}$, $18^{\circ} 25^{\prime} 13^{\prime \prime} \mathrm{E}, \quad 313 \mathrm{~m}$ a.s.l., 04.04.2006, Leg. Klára Dózsa-Farkas, János Farkas, Gergely Boros (DNA ID 105); 1 specimen, Mt. Bakony, Bakonybél - Pápa, beech forest, decaying bark on tree stump, $47^{\circ} 17^{\prime} 27^{\prime \prime} \mathrm{N} 17^{\circ} 42^{\prime} 20^{\prime \prime} \mathrm{E}$, 285 m a.s.l., 17.07.2008, Leg. Klára Dózsa-Farkas, Jenő Kontschán, Balázs Németh (DNA ID 203); 1 specimen, Mt. Bakony, beech forest, decaying bark on tree stump, $47^{\circ} 06^{\prime} 42^{\prime \prime} \mathrm{N} 17^{\circ} 47^{\prime} 19^{\prime \prime} \mathrm{E}, 370 \mathrm{~m}$ a.s.l., 05.01.2011, Leg. Klára Dózsa-Farkas, Jenő Kontschán (DNA ID bryehl-bank); 1 specimen, Mt. Gerecse, Tardos, mixed deciduous forest, decaying bark on tree stump, 47 $40^{\prime} 15^{\prime \prime} \mathrm{N} 18^{\circ} 26^{\prime} 42^{\prime \prime} \mathrm{E}$, 270 m a.s.1., 24.11.2009, Leg. Klára Dózsa-Farkas, Jenő Kontschán (DNA ID 238). Germany: 1 specimen, Lake Stanberg, mixed deciduous forest, $48^{\circ} 00^{\prime} \mathrm{N} 11^{\circ} 22^{\prime} \mathrm{E}$, 10.03.2008, Leg. Klára Dózsa-Farkas, András Dózsa-Farkas (DNA ID 176). See additional details in Cech et al. (2012) and Dózsa-Farkas et al. (2012). 
Short description of the Korean specimens - The following combination of characters: (1) middle size (11-20 mm in vivo), segments 38-52; (2) chaetae maximum 6-7 (8) per bundle, sigmoid without nodulus; (3) clitellum girdle shaped; (4) seven pairs of preclitellar nephridia; (5) coelomocytes discoid; (6) pharyngeal glands free dorsally and with ventral lobes; (7) two pairs of oesophageal appendages in VI with sponge-like structure not pulsating in living worms; (8) sperm funnels pear-shaped or cylindrical, 70-120 $\mu \mathrm{m}$ long and 1.2-2.0 times longer than wide in vivo; (9) midgut pars tumida XXIII-XXIX, occupying 3-6 segments; (10) male copulatory organs spherical, diameter about 50-70 $\mu \mathrm{m}$, fixed; (11) spermathecae communicating with oesophagus, ectal ducts 110-180 $\mu \mathrm{m}$ long and 20-25 $\mu \mathrm{m}$ wide, the ampullae lemon-shaped, diameter 30-50 $\mu \mathrm{m}$, ectal gland stalked, 30-50 $\mu \mathrm{m}$ long fixed.

Detailed description of the Korean specimens - Middle sized worms. Length 11.0-19.8 $\mathrm{mm}$, width 310-610 $\mu \mathrm{m}$ at VIII and 350-690 $\mu \mathrm{m}$ at clitellum in vivo; fixed specimens: length 5.1-16.3 mm, width 410-570 $\mu \mathrm{m}$ at VIII and $420-600 \mu \mathrm{m}$ at clitellum; segments 38-52. Chaetae sigmoid, without nodulus. Chaetae in a bundle arranged in asymmetric fan, of unequal size, those towards dorsal and ventral midlines of body gradually smaller; largest ventral chaetae in a bundle preclitellarly 53-62 $\mu \mathrm{m}$, the shortest 30-37 $\mu \mathrm{m}$ long and 5-3 $\mu \mathrm{m}$ wide. In terminal segments the largest chaetae $70-80 \mu \mathrm{m}$ long. Chaetal formula (2),3,4,5 - 3,4: $(2,3), 4,5,6,7,(8)-6,5,4,3$ (2). Chaetae absent at XII. Three or four rows of epidermal gland cells per segment (Fig. 1D). Head pore at 0/1, a transversal slit (Fig. 1C). Body wall 28-40 $\mu \mathrm{m}$ thick, cuticle thin, 1.0-1.5 $\mu \mathrm{m}$. Clitellum over XII-1/2 XIII, girdle-shaped, small hyalocytes and granulocytes in irregular rows dorsally and ventrally arranged alike (Figs 1E-G).

Brain 165-220 $\mu \mathrm{m}$ long and 1.3-2.0 times longer than wide in vivo (Fig. 1A), 125-160 $\mu \mathrm{m}$ long and 1.1-1.6 times longer than wide when fixed (Fig. 1B), anteriorly convex, posteriorly straight. Pharyngeal glands 3 pairs in IV-VI, most often all free dorsally with ventral lobes (Figs 1I, K, 2J, K), sometimes first pair connected dorsally. Two pairs of oesophageal appendages in VI (Figs 1I-K) with sponge-like structure not pulsating in living worms (about 125-180 $\mu \mathrm{m}$ long in vivo, 80-125 $\mu \mathrm{m}$ long, fixed). Seven pairs of preclitellar nephridia from $4 / 5$ to 10/11; anteseptale consisting of funnel and some coil of canal, efferent ducts arising antero-ventrally. Coelomocytes nucleate, discoid, about 17-28 $\mu \mathrm{m}$ long in vivo (16-25 $\mu \mathrm{m}$, fixed), finely granulated, light brown in transmitted light in vivo (Figs 1I-J) and with clearly visible nucleus in fixed worms (Fig. 1H). Dorsal blood vessel from XII, blood colourless. Anterior bifurcation in peristomium. The part of midgut in XXIII-XXIX, 3-6 segments long with distinctive hyaline and granulated networking cell structure in the intestinal wall, is different from the structure of other parts of the intestine (Fig. 1M). Chloragocytes from VI, about 25-50 $\mu \mathrm{m}$ large in vivo. Intestine filled with decaying wood debris (Fig. 1L). Seminal vesicle small in XI or absent. Sperm funnels (Figs 2C-G), pearshaped or cylindrical 70-120 $\mu \mathrm{m}$ long and 1.2-2.0 times longer than wide in vivo (60-95 $\mu \mathrm{m}$ long and 1.1-1.6 times longer than wide in fixed specimens). Collars about as wide as funnel body or slightly narrower. Diameter of sperm ducts $6-9 \mu \mathrm{m}$. Spermatozoa 70-130 $\mu \mathrm{m}$ long, heads 30-45 $\mu \mathrm{m}$ in vivo (Fig. 2E), (50-75 $\mu \mathrm{m}$ and 25-30 $\mu \mathrm{m}$, respectively, when fixed). Male glandular bulbs about $85-110 \mu \mathrm{m}$ long and 50-80 $\mu \mathrm{m}$ wide in vivo (48-70 $\mu \mathrm{m}$ long and 50-70 $\mu \mathrm{m}$ wide when fixed) (Figs 1G, 2B). Bursal slits longitudinal, slightly bent laterally (Fig. 2A). Subneural glands absent. Spermathecal ectal ducts about 135-180 $\mu \mathrm{m}$ long and 20-25 $\mu \mathrm{m}$ wide in vivo (110-180 $\mu \mathrm{m}$ long and 20-25 $\mu \mathrm{m}$ wide when fixed), one or two stalked ectal glands 30-50 $\mu \mathrm{m}$ long (Figs 2L-M). Ampullae lemon-shaped, diameter 30-50 $\mu \mathrm{m}$ when fixed. The ental ducts merging entally and with joint opening into oesophagus in VI (Figs 2H-K). 1-2 mature egg at a time. 

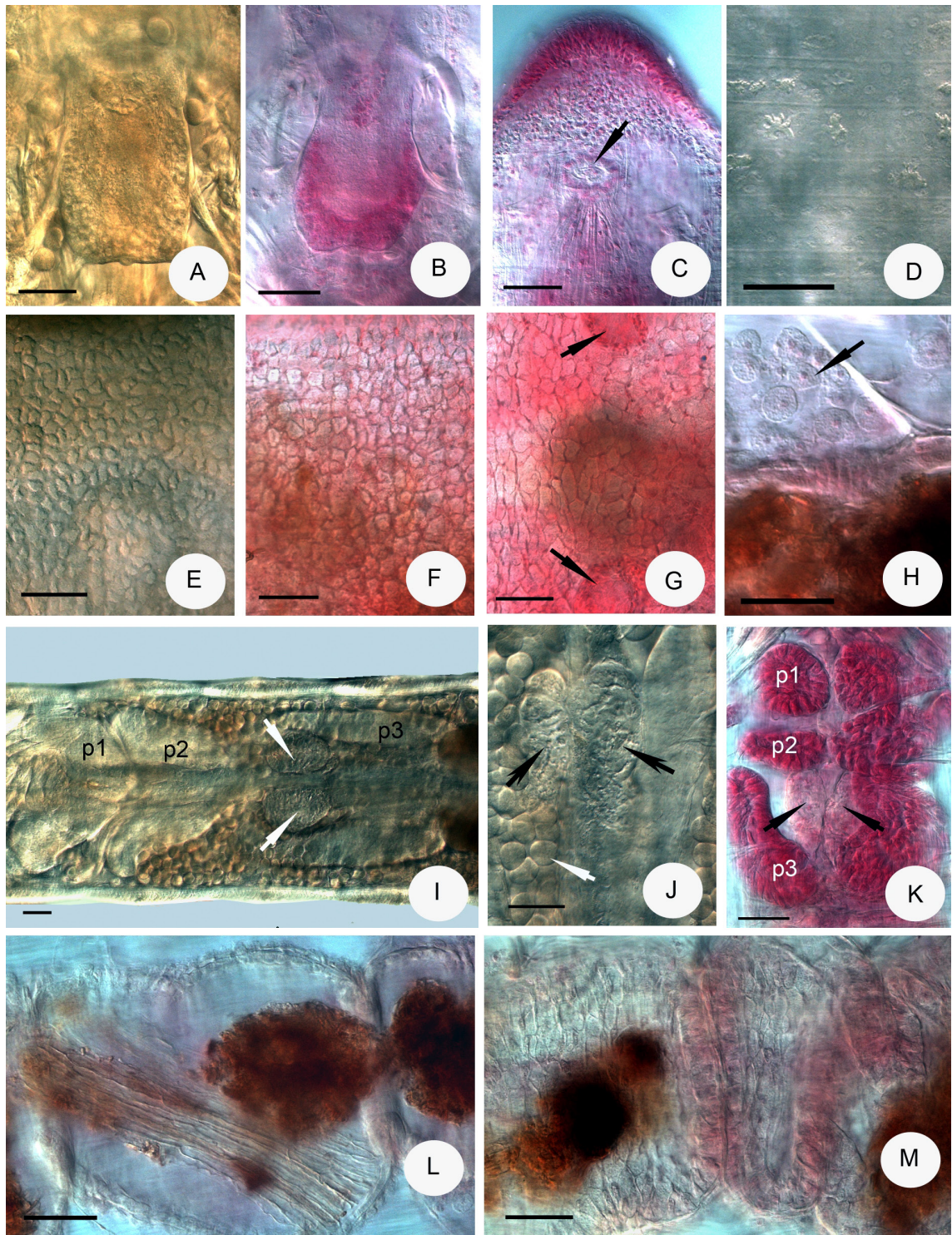

Fig. 1. Micrograph of Korean Bryodrilus cf. ehlersi. A-B = Brain. $C=$ Head pore (marked with arrow) $. \mathrm{D}=$ Epidermal gland cells. $\mathrm{E}-\mathrm{F}=$ Clitellar gland cells, dorsal view $. \mathrm{G}=\mathrm{Clitellar}$ gland cells, ventral view (penial bulbs marked with arrows). $\mathrm{H}=$ Coelomocytes (marked with arrow). I = Segments IV-VI, dorsal view (p1-p3 = pharyngeal glands, oesophageal appendages marked with arrows, coelom full with brown round coelomocytes). J = Oesophageal appendages, dorsal view (marked with black arrows, coelomocytes marked with white arrow). $\mathrm{K}=$ Pharyngeal glands (= p1-p3, oesophageal appendages marked with arrows). $\mathrm{L}=$ Decaying wood debris in intestine. $\mathrm{M}=$ Midgut in XXIII-XXIX. (A, D-E, I-J in vivo; $\mathrm{B}-\mathrm{C}, \mathrm{F}-\mathrm{H}, \mathrm{K}-\mathrm{M}$ fixed, stained. Scale bars: $50 \mu \mathrm{m})$ 

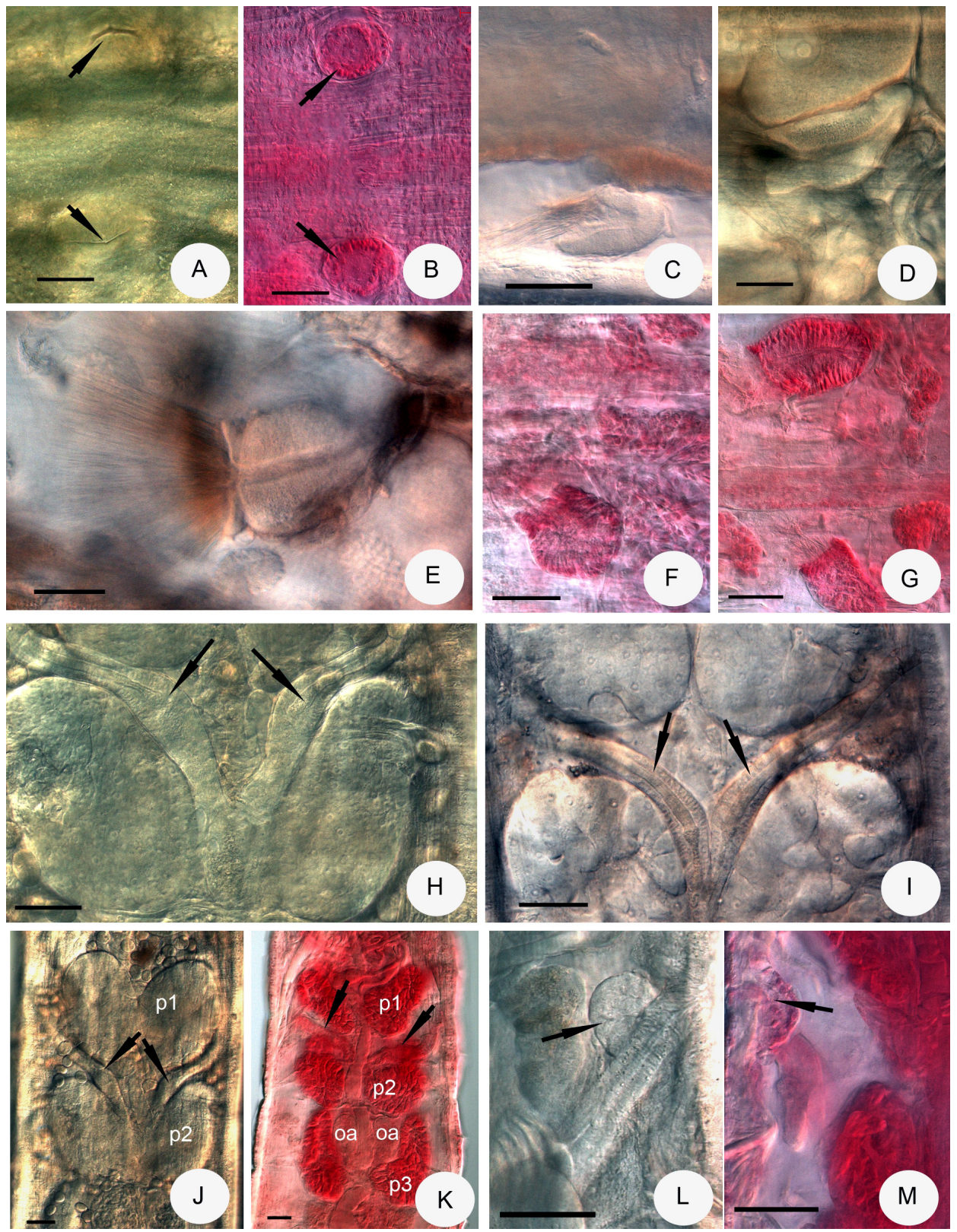

Fig. 2. Micrograph of Korean Bryodrilus cf. ehlersi. A = Bursal slits, ventral view (marked with arrows). $\mathrm{B}=$ Male copulatory apparate (penial bulbs, marked with arrows). $\mathrm{C}-\mathrm{G}=$ Sperm funnels. $\mathrm{H}-\mathrm{K}=$ Spermathecae, dorsal view (marked with arrows, $\mathrm{p} 1-\mathrm{p} 3$ = pharyngeal glands). $\mathrm{L}-\mathrm{M}=$ Ectal glands of spermathecae, lateral view (marked with arrows). (A, C-E, H-J, L in vivo; B, F-G, K, M fixed, stained. Scale bars: $50 \mu \mathrm{m}$ ) 
Table 2. Comparison of morphological traits of Bryodrilus ehlersi specimens collected from Europe and Korea. Abbreviations: $\mathrm{BE}=$ B. ehlersi (Europe); BK = B. cf. ehlersi (Korea).

\begin{tabular}{|c|c|c|c|c|}
\hline \multirow[b]{3}{*}{ Segments (number) } & $\mathrm{BE}$ & BK & $\mathrm{BE}$ & BK \\
\hline & \multicolumn{2}{|c|}{ in vivo } & \multicolumn{2}{|c|}{ fixed } \\
\hline & $40-53$ & $38-52$ & & \\
\hline Length (mm) & $9.5-21.0$ & $11.0-19.8$ & $6.0-10.0$ & $5.1-9.2$ \\
\hline Width at VIII $(\mu \mathrm{m})$ & $400-600$ & $310-610$ & $400-520$ & $410-570$ \\
\hline Width at XII $(\mu \mathrm{m})$ & $450-700$ & $350-690$ & $410-600$ & $420-600$ \\
\hline Maximum number of chaetae & $6(7-8)$ & $6-7(8)$ & & \\
\hline Length of coelomocytes $(\mu \mathrm{m})$ & $15-30$ & $17-28$ & $13-28$ & $16-25$ \\
\hline Length : width of brain & $1.6-1.9$ & $1.3-2.0$ & $1.4-1.7$ & $1.1-1.6$ \\
\hline Headpore & $0 / 1$ & transverse & $0 / 1$ & transverse \\
\hline No. of nephridia preclitellarly & 7 & 7 & & \\
\hline Length of oesophageal appendage $(\mu \mathrm{m})$ & $120-165$ & $125-180$ & 71-119 & $80-125$ \\
\hline Length of sperm funnel ( $\mu \mathrm{m})$ & $73-125$ & $45-120$ & $50-150$ & $60-95$ \\
\hline Length : width of sperm funnel & $1.2-2.3$ & $1.2-2.0$ & $1.2-2.8$ & $1.1-1.6$ \\
\hline Lenght of spermatozoa $(\mu \mathrm{m})$ & $82-120$ & $70-130$ & $50-90$ & 50-105 \\
\hline Heads of spermatozoa $(\mu \mathrm{m})$ & $30-40$ & $30-45$ & $25-30$ & $25-40$ \\
\hline Length of penial bulb $(\mu \mathrm{m})$ & $60-84$ & 85-110 & $55-80$ & $48-70$ \\
\hline Width of penial bulb $(\mu \mathrm{m})$ & $50-60$ & $50-80$ & $55-68$ & $50-70$ \\
\hline Height of penial bulb $(\mu \mathrm{m})$ & $40-47$ & $30-40$ & $55-65$ & $32-40$ \\
\hline Length of spermathecal duct $(\mu \mathrm{m})$ & 140-200 & $135-180$ & $130-180$ & $110-180$ \\
\hline Width of spermathecal duct $(\mu \mathrm{m})$ & $21-28$ & $20-25$ & $20-23$ & $20-25$ \\
\hline Diameter of ampulla $(\mu \mathrm{m})$ & $30-47$ & $33-40$ & $40-50$ & $30-50$ \\
\hline Length of ectal glands $(\mu \mathrm{m})$ & $40-60$ & $43-65$ & $35-60$ & $30-50$ \\
\hline Origin of dorsal blood vessel & XII & XII & & \\
\hline Body wall $(\mu \mathrm{m})$ & $23-45$ & $29-32$ & $32-34$ & $28-40$ \\
\hline Cuticle $(\mu \mathrm{m})$ & $<1$ & 1 & $<1$ & $1-1.5$ \\
\hline
\end{tabular}

Remarks - The morphological characters of the Korean specimens agree with those of Bryodrilus ehlersi, a species common in Northern and Central Europe. The following external and internal characters are essentially the same: size, length, diameter (in vivo and fixed alike) and segment number, maximum number of chaetae (6-7), number of nephridia preclitellarly (7 pairs), length of spermatozoa and sperm heads, origin of dorsal blood vessel (in XII), etc. (Table 2). Very conspicuous is the similarity of the oesophageal appendages (sponge-like structure not pulsating), which was exclusive for B. ehlersi so far in the genus (Figs 1I-K vs. Figs 3F-H). Further similar morphological features 
are: the position of head pore (Fig. 1C vs. Fig. 3B), the shape and size of brain (Figs 1A-B vs. Fig. 3A); the girdle-shaped clitellum, hyaline and granular gland cells mostly in irregular rows dorsally and ventrally (Figs $1 \mathrm{E}-\mathrm{G}$ vs. Figs $3 \mathrm{C}-\mathrm{D}, \mathrm{J})$; all three pharyngeal glands with ventral lobes and free dorsally (Figs
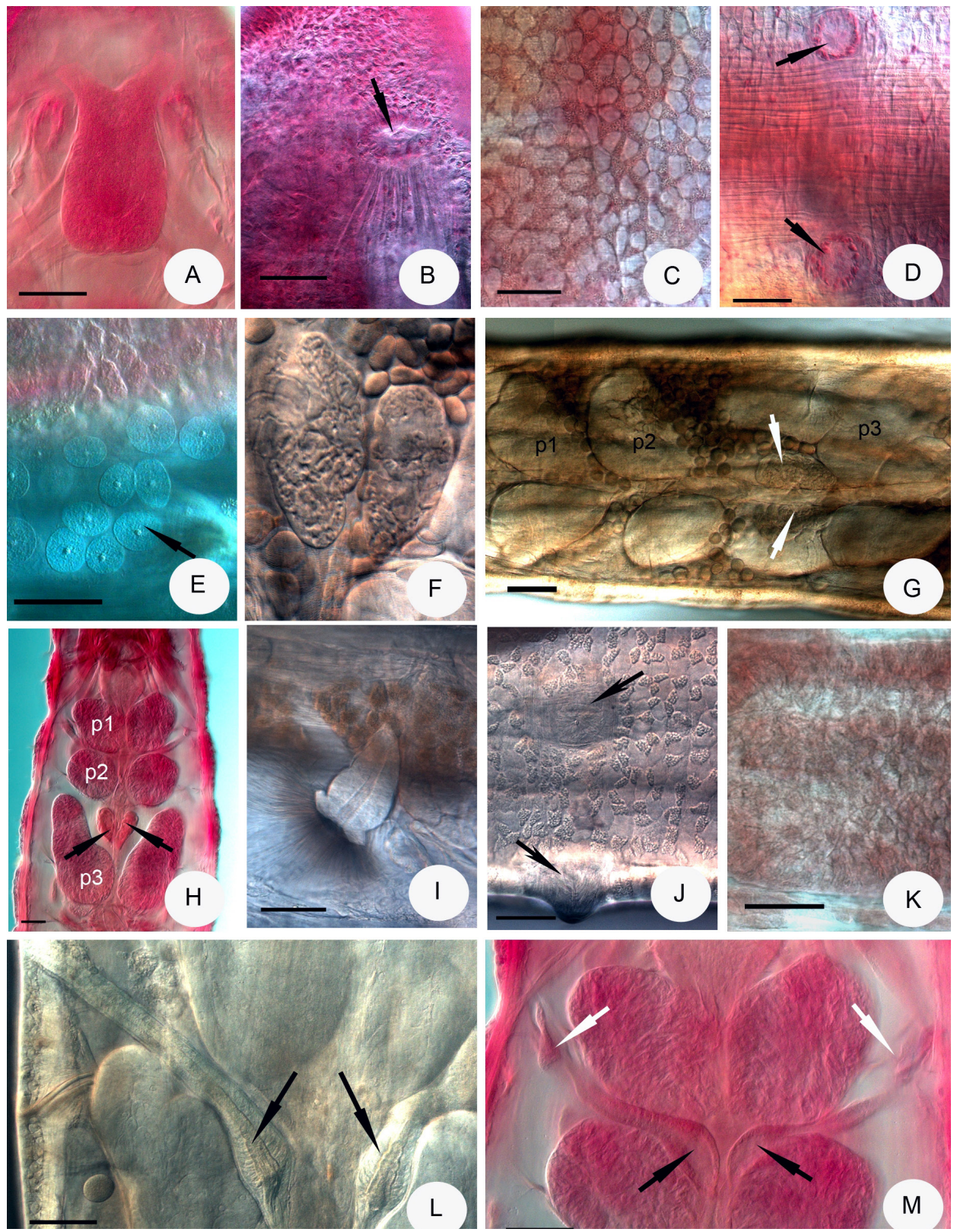
1I, K vs. Figs 3G-H); coelomocytes discoid, light brown in vivo (Figs 1I-J vs. Figs $3 \mathrm{~F}-\mathrm{G}$ ) and with well visible nucleus in the fixed specimens (Fig. $1 \mathrm{H}$ vs. Fig. 3E); the networking cell structure of the midgut in the same place of the gut (Fig. $1 \mathrm{M}$ vs. Fig. 3K); shape and size of sperm funnels (Figs $2 \mathrm{C}-\mathrm{G}$ vs. Fig. $3 \mathrm{I})$; form of spermathecae (Figs $2 \mathrm{H}-\mathrm{K}$ vs. Figs $3 \mathrm{~L}-\mathrm{M}$ ); the shape, number and size of ectal glands (Figs 2L-M vs. Fig. 3M). Only the male copulatory organs were slightly larger in vivo and smaller when fixed in the Korean specimens (Table 2, Figs 1G, 2B vs. Figs 3D, J). Furthermore, they prefer to live in decaying wood, as their intestine was full with decaying wood debris, similarly as in the case of the studied European specimens. In summary, the specimens collected from Korea and Europe cannot be differentiated morphologically.

\section{Results of DNA-based analysis}

In total, 4, 6 and 6 sequences were generated from the Bryodrilus ehlersi specimens collected from different sites in the case of ITS, CO1 and H3, respectively. Additional sequences determined in previous studies were also used for comparison (Table 1). Unfortunately, we failed to amplify the ITS region from two specimens, which was probably due to the improper hybridization of PCR primer sequences to the extracted genomic DNA. Results of molecular studies showed that the Korean Bryodrilus ehlersi specimens may represent a cryptic species since based on the three studied regions, sequences acquired from these specimens formed distinct lineages on the phylogenetic trees (Figs 4 \& 5).

\section{DISCUSSION}

Molecular analyses based on the mitochondrial cytochrome c oxidase subunit I gene, the nuclear histone $\mathrm{H3}$ gene and the nuclear ribosomal ITS region showed unambiguously that the specimens collected in South Korea and identified morphologically as Bryodrilus ehlersi represent a distinct evo-

Fig. 3. Micrograph of European Bryodrilus ehlersi. $A=$ Brain. $B=$ Head pore (marked with arrow). $\mathrm{C}=$ Clitellar gland cells, dorsal view. $\mathrm{D}, \mathrm{J}=$ Clitellar gland cells, ventral view (penial bulbs marked with arrows). $\mathrm{E}=$ Coelomocytes (marked with arrow). $\mathrm{F}=$ Oesophageal appendages in VI. G = Three pairs of pharyngeal glands, brown, round coelomocytes in coelom and oesophageal appendages, dorsal view (marked with arrows). $\mathrm{H}=$ Segments III-VI, dorsal view (p1-p3 = pharyngeal glands, oesophageal appendages marked with arrows). $\mathrm{I}$ = Sperm funnel. $\mathrm{J}=$ Male copulatory organ. $\mathrm{K}=$ Networking cell structure in XXVI. $\mathrm{L}-\mathrm{M}=$ Spermathecae, dorsal view (marked with black arrows, in $\mathrm{M}$ ectal glands marked with white arrows). (F-G, I-J, L in vivo; A-E, H, K, M fixed, stained. Scale bars: $50 \mu \mathrm{m}$ ). [A, $\mathrm{H}, \mathrm{M}$ micrograph of the paratype P.21.2. of B. glandulosus (DózsA-FARKAs, 1990) which was synonymised with B. ehlersi by CECH et al. (2012)] 

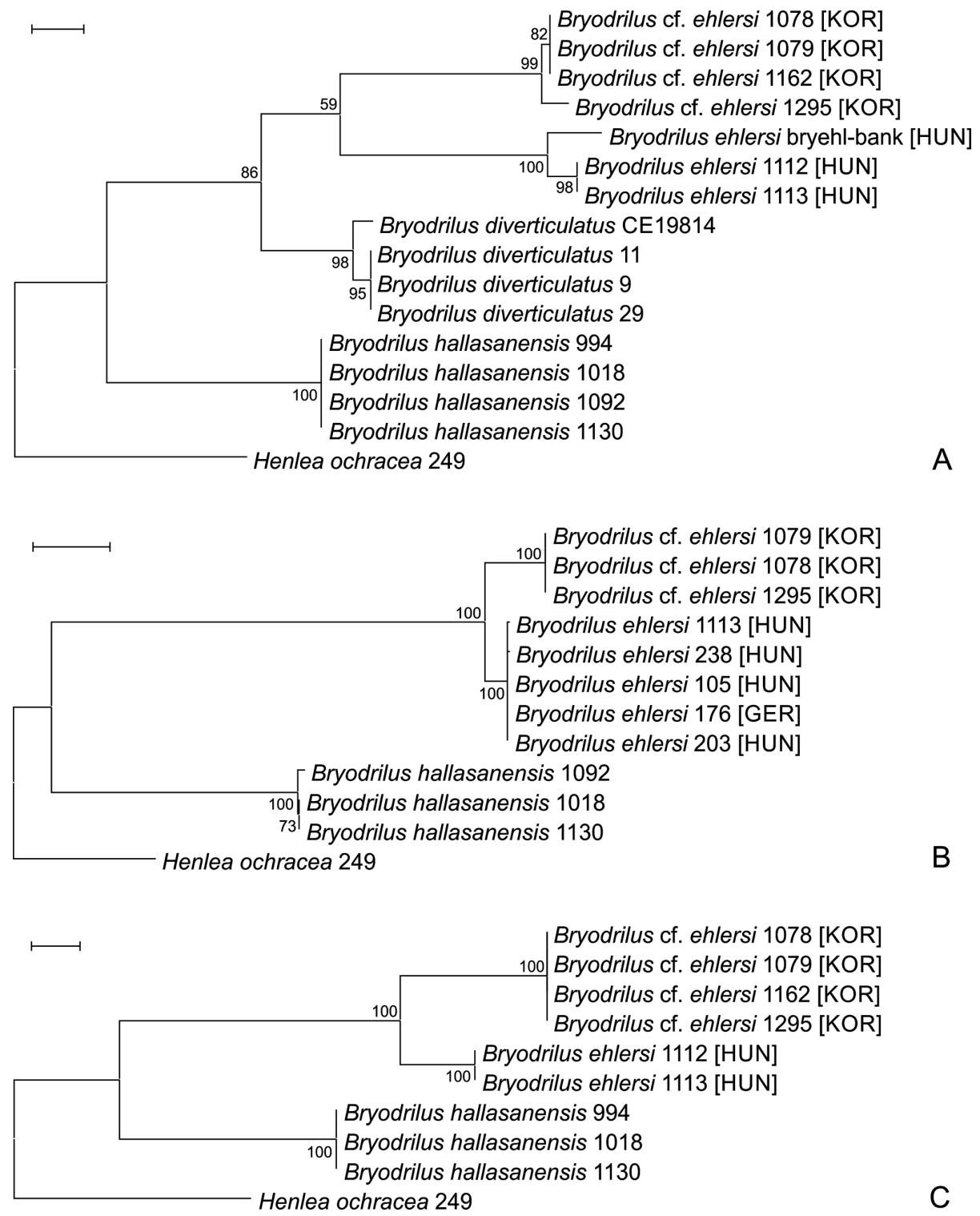

C

Fig. 4. Bryodrilus species, maximum likelihood (ML) trees of the CO1 region (A), ITS (B) and $\mathrm{H} 3$ genes $(\mathrm{C})$. Bootstrap values greater than 50 are shown at the nodes. Accession codes of sequences with collection information are given in Table $1 . \mathrm{A}=\mathrm{ML}$ tree of the CO1 gene based on 606 nucleotide positions (Tamura-Nei model). $\mathrm{B}=\mathrm{ML}$ tree of the ITS region based on 765 nucleotide positions (Tamura 3-parameter model). $\mathrm{C}=\mathrm{ML}$ tree of the $\mathrm{H} 3$ gene based on 218 nucleotide positions (Tamura 3-parameter model). Scale bars, 0.05 substitutions per nucleotide position (except for $\mathrm{H} 3$, where the scale is 0.01 ). For B. ehlersi specimens, the abbreviation of sample origin is shown in brackets (KOR = Korea, $\mathrm{HUN}=$ Hungary, GER = Germany) 


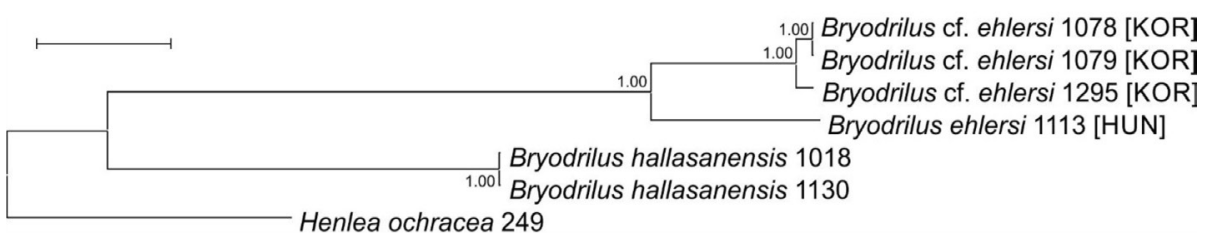

Fig. 5. Bryodrilus species, concatenated phylogenetic tree based on 1599 nucleotide positions (which comprised the CO1, H3 and ITS genetic markers). Bayesian posterior probabilities are shown at the nodes. Scale bar, 0.05 substitutions per nucleotide position. For B. ehlersi specimens, the abbreviation of sample origin is shown in brackets ( $\mathrm{KOR}=\mathrm{Korea}$, HUN = Hungary)

lutionary lineage. Therefore, the Korean population may represent a cryptic species, since no unambiguous distinguishing morphological features were found in comparison with B. ehlersi specimens previously (see details in $\mathrm{CECH}_{\mathrm{E}}$ et al. 2012) and recently collected from different sites in Central Europe (Hungary: Mt. Villány, Mt. Bakony, Mt. Gerecse, Kőszeg Mts and Börzsöny Mts; Germany: near Munich). Decaying wood debris and soil samples from the type locality of Bryodrilus ehlersi (Harz Mts, Germany) was also collected twice in July and December 2019 by W. Rackow (National Park Harz), but unfortunately not any worms belonging to this species were possible to be extracted (7 samples, data not shown). Hence, Korean specimens could not be formally described as a different species, since it was not possible to compare them with specimens collected from the type locality of $B$. ehlersi.

Bryodrilus ehlersi is common in Northern and Central Europe (Schmelz \& Collado 2010). Outside Europe, this species has been recorded from Canada (Nurminen 1973a), the Arctic (Piper et al. 1982) and Lake Bajkal (Nurminen 1973b). The taxonomic identity of these nominal extra-European populations should also be confirmed by DNA-based methods in the future.

Revealing cryptic genetic diversity in some cases resulted in the description of new enchytraeid species. Previously, most of them were described from Europe (Westheide \& Graefe 1992, De Wit \& Erséus 2010, Martinsson et al. 2015a,b, Martinsson et al. 2018), but two cryptic species pairs were recorded from areas outside Europe (from South Africa and from Japan), resulting in the description of the new species Grania cryptica (Prantoni et al. 2016) and Enchytraeus japonensis (NAKAMURA 1993).

In this paper, it has been demonstrated that the importance of DNAbased analyses in the taxonomy of annelid species is not restricted to provide barcodes during the description of a new species for subsequent studies, but is also a tool for the recognition of cryptic diversity, which could initiate new species descriptions in the future. 
Acknowledgements - This study was supported by the National Research Foundation of Korea (NRF) funded by the Ministry of Education (NRF-2019R1I1A3A01060987), by the National Institute of Biological Resources (NIBR) funded by the Ministry of Environment of Republic of Korea (NIBR201902204), and by the National Research, Development and Innovation Office, Hungary (108582 NKFIH). T.F. was supported by the János Bolyai Research Scholarship of the Hungarian Academy of Sciences (grant no. BO/00837/20/8) and H.N. by the New Excellence Program of the Ministry for Innovation and Technology, Hungary (grant no. ÚNKP-20-4-I-ELTE-281). The authors are thankful to Rüdiger M. Schmelz and an anonymous reviewer for their suggestions, and to Wolfgang Rackow for collecting samples.

\section{REFERENCES}

Ávila-Jiménez, M. L., Solhøy, T., Gwiazdowicz, D. J., Fjellberg, A., Dózsa-Farkas, K., Monson, F., DeSmet, W. H., Stur, E., Ekrem, T. \& Coulson, S. J. (2019): The soil invertebrate fauna of Edgeøya, Svalbard: Arctic landscape community composition reflects biogeography patterns. - Polar Biology 42: 837-850. https://doi.org/10.1007/ s00300-019-02471-x

CECh, G., Boros, G. \& Dózsa-Farkas, K. (2012): Revision of Bryodrilus glandulosus (DózsaFarkas, 1990) and Mesenchytraeus kuehnelti Dózsa-Farkas, 1991 (Oligochaeta: Enchytraeidae) using morphological and molecular data. - Zoologischer Anzeiger 251: 253-262. https://doi.org/10.1016/j.jcz.2011.09.005

Colgan, D. J., Mclauchlan, A. A., Wilson, G. D. F., Livingston, S. P., Edgecombe, G. D., Macaranas, J., Cassis, G. \& Gray, M. R. (1998): Histone H3 and U2 snRNA DNA sequences and arthropod molecular evolution. - Australian Journal of Zoology 46: 419437. https://doi.org/10.1071/ZO98048

De Wit, P. \& Erséus C. (2010): Genetic variation and phylogeny of Scandinavian species of Grania (Annelida: Clitellata: Enchytraeidae), with the discovery of a cryptic species. - Journal of Zoological Systematics and Evolutionary Research 48: 285-293. https://doi. org/10.1111/j.1439-0469.2010.00571.x

Dózsa-Farkas, K., Porco, D. \& Boros, G. (2012): Are Bryodrilus parvus Nurminen, 1970 and Bryodrilus librus (Nielsen and Christensen, 1959) (Annelida: Enchytraeidae) really different species? A revision based on DNA barcodes and morphological data. - Zootaxa 3276: 38-50. https://doi.org/10.11646/zootaxa.3276.1.2

Dózsa-Farkas, K., Felföldi, T. \& Hong, Y. (2015): New enchytraeid species (Enchytraeidae, Oligochaeta) from Korea. - Zootaxa 4006(1): 171-197. https://doi.org/10.11646/ zootaxa.4006.1.9

Dózsa-Farkas, K. \& Felföldi, T. (2017): Comparative morphological and molecular taxonomic study of six Achaeta species (Clitellata: Enchytraeidae) with the description of a new Achaeta species from Kőszeg Mountains, Hungary. - Zootaxa 4273(2): 177-194. https://doi.org/10.11646/zootaxa.4273.2.2

Dózsa-Farkas, K., Csitári, B. \& Felföldi, T. (2017): A new Cernosvitoviella species (Clitellata: Enchytraeidae) and its comparison with other Cernosvitoviella species from Sphagnum mires in Hungary. - Zootaxa 4254(3): 322-338. https://doi.org/10.11646/ zootaxa.4254.3.2 
Dózsa-Farkas, K., Felföldi, T., Nagy, H. \& Hong, Y. (2018): New enchytraeid species from Mount Hallasan (Jeju Island, Korea) (Enchytraeidae, Oligochaeta). - Zootaxa 4496(1): 337-381. https://doi.org/10.11646/zootaxa.4496.1.27

Dózsa-Farkas, K., Felföldi, T., Nagy, H. \& Hong, Y. (2019a): Two new enchytraeid species from Jeju Island, Korea (Annelida, Clitellata). - ZooKeys 824: 87-108. https://doi. org/10.3897/zookeys.824.25544

Dózsa-Farkas, K., NagY, H., Felföldi, T. \& Hong, Y. (2019b): Decimodrilus, a new enchytraeid genus from Korea (Annelida, Clitellata, Enchytraeidae). - Zootaxa 4661: 385-399. https://doi.org/10.11646/zootaxa.4661.2.7

Folmer, O., Black, M., Hoen, W., Lutz, R. \& Vrijenhoek, R. (1994): DNA primers for amplification of mitochondrial cytochrome c oxidase subunit I from diverse metazoan invertebrates. - Molecular Marine Biology and Biotechnology 3: 294-299.

Huelsenbeck, J. P. \& Ronquist, F. (2001): MRBAYES: Bayesian inference of phylogeny. Bioinformatics 17: 754-755. https://doi.org/10.1093/bioinformatics/17.8.754

Kane, R. A. \& Rollinson, D. (1994): Repetitive sequences in the ribosomal DNA internal transcribed spacer of Schistosoma haematobium, Schistosoma intercalatum and Schistosoma mattheii. - Molecular and Biochemical Parasitology 63: 153-156. https://doi. org/10.1016/0166-6851(94)90018-3

Kumar, S., Stecher, G. \& Tamura, K. (2016): MEGA7: Molecular Evolutionary Genetics Analysis version 7.0 for bigger datasets. - Molecular Biology and Evolution 33: 18701874. https://doi.org/10.1093/molbev/msw054

Martinsson, S., Rota, E. \& ErsÉus, C. (2015a): Revision of Cognettia (Clitellata, Enchytraeidae): reestablishment of Chamaedrilus and description of cryptic species in the sphagnetorum complex. - Systematics and Biodiversity 13(3): 257-277. https://doi.org/ 10.1080/14772000.2014.986555

Martinsson, S., Rota, E. \& Erséus, C. (2015b): On the identity of Chamaedrilus glandulosus (Michaelsen, 1888) (Clitellata, Enchytraeidae), with the description of a new species. - ZooKeys 501: 1-14. https://doi.org/10.3897/zookeys.501.9279

Martinsson, S., Dózsa-Farkas, K., Rota, E. \& Erséus, C. (2017): Placing the forgotten: On the phylogenetic positions of Euenchytraeus and Chamaedrilus in an updated enchytraeid phylogeny (Clitellata: Enchytraeidae). - Invertebrate Systematics 31(1): 85-90. https://doi.org/10.1071/IS16042

Martinsson, S. \& Erséus, C. (2018): Cryptic diversity in supposedly species-poor genera of Enchytraeidae (Annelida: Clitellata). - Zoological Journal of the Linnean Society 183: 749-762. https://doi.org/10.1093/zoolinnean/zlx084

Matamoros, L., Rota, E. \& Erséus, C. (2012): Cryptic diversity among the achaetous Marionina (Annelida, Clitellata, Enchytraeidae). - Systematics and Biodiversity 10(4): 509_ 525. https://doi.org/10.1080/14772000.2012.723640

NAKAmURA, Y. (1993): A new fragmenting enchytraeid species, Enchytraeus japonensis from a cropped Kuroboku soil in Fukushima, Northern Japan (enchytraeids in Japan 5). Edaphologia 50: 37-39.

Nielsen, C. O. \& Christensen, B. (1959): The Enchytraeidae - critical revision and taxonomy of European species (Studies on Enchytraeidae VII). - Natura Jutlandica 8-9: $1-160$.

Nurminen, M. (1970): Records of Enchytraeidae (Oligochaeta) from the west coast of Greenland. - Annales Zoologici Fennici 7: 199-209.

Nurminen, M. (1973a): Enchytraeidae (Oligochaeta) from the Arctic archipelago of Canada. - Annales Zoologici Fennici 10: 404-411. 
Nurminen, M. (1973b): Enchytraeidae (Oligochaeta) from the vicinity of the Lake Baikal, Siberia. - Annales Zoologici Fennici 10: 478-482.

O'Connor, F. B. (1962): The extraction of Enchytraeidae from soil. Pp. 279-285. - In: MurPHY, P. W. (ed.): Progress in soil zoology. - Butterworths Publishers, London.

Piper, S. R., MacLean, S. F. \& Christensen, B. (1982): Enchytraeidae (Oligochaeta) from taiga and tundra habitats of northeastern U.S.S.R. - Canadian Journal of Zoology 60(11): 2594-2609. https://doi.org/10.1139/z82-334

Prantoni, A. L., De Wit, P. \& Erséus, C. (2016): First reports of Grania (Clitellata: Enchytraeidae) from Africa and South America: molecular phylogeny and descriptions of nine new species. - Zoological Journal of the Linnean Society 176: 485-510. https://doi. org/10.1111/zoj.12333

Schmelz, R. M. \& Collado, R. (2010): A guide to European terrestrial and freshwater species of Enchytraeidae (Oligochaeta). - Soil Organisms 82(1): 1-176.

Schmelz, R. M., Beylich, A., Boros, G., Dózsa-Farkas, K., Graefe, U., Hong, Y., Römbke, J., Schlaghamersky, J. \& Martinsson, S. (2017): How to deal with cryptic species in Enchytraeidae, with recommendations on taxonomical descriptions. - Opuscula Zoologica (Budapest) 48(Suppl. 2): 45-51. https://doi.org/10.18348/opzool.2017.S2.45

UDE, H. (1892): Ein neues Enchytraeiden-Genus. - Zoologischer Anzeiger 15: 344-345.

Vaidya, G., Lohman, D.J. \& Meier, R. (2011): SequenceMatrix: concatenation software for the fast assembly of multigene datasets with character set and codon information. Cladistics 27: 171-180. https://doi.org/10.1111/j.1096-0031.2010.00329.x

Westheide, W. \& Graefe, U. (1992): Two new terrestrial Enchytraeus species (Oligochaeta, Annelida). - Journal of Natural History 26: 479-488.

Received January 29, 2020, accepted May 1, 2020, published November 13, 2020 